
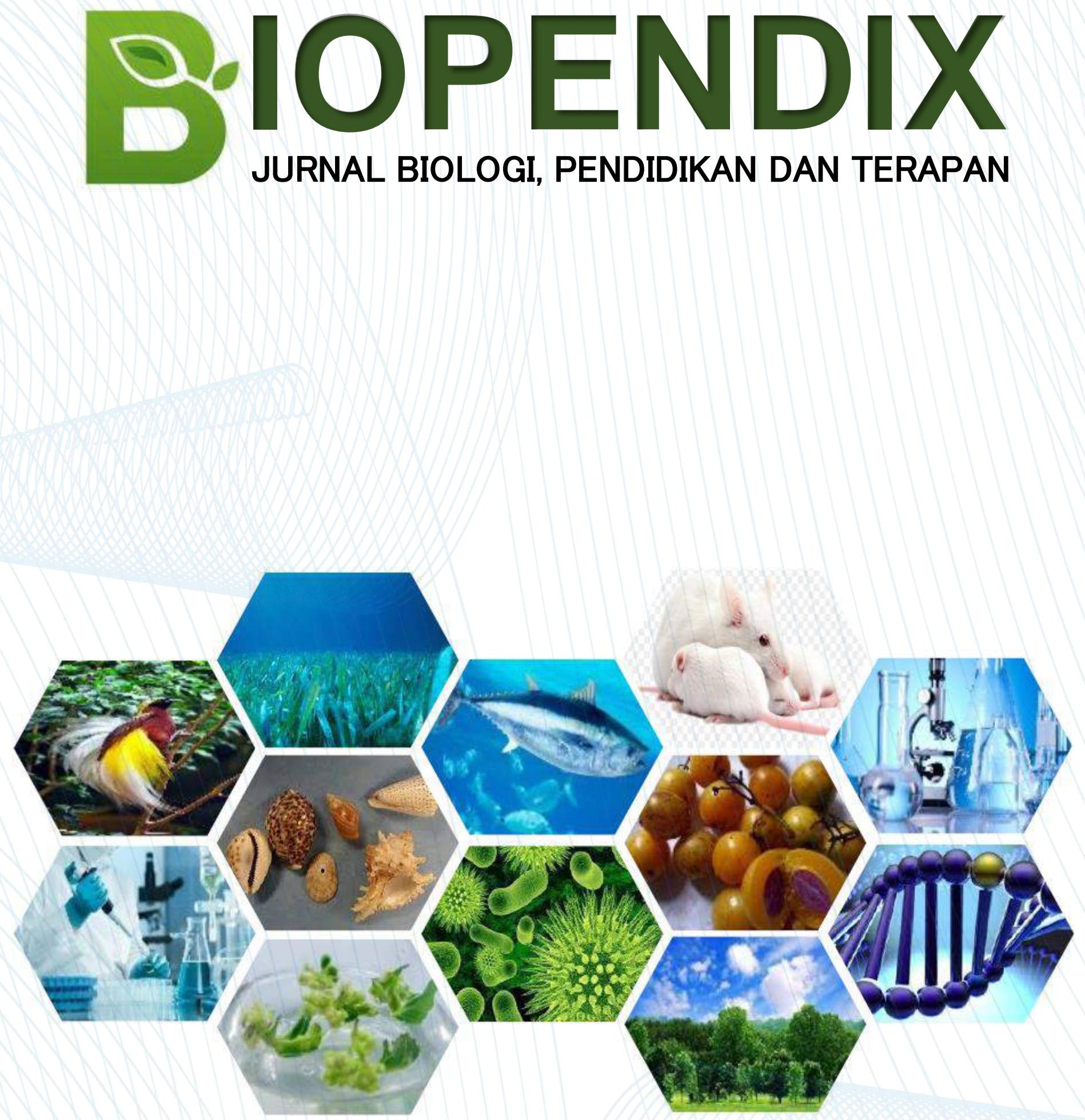

PUBLISHER BY:

BIOLOGY EDUCATION, UNPATTI AMBON - MALUKU 


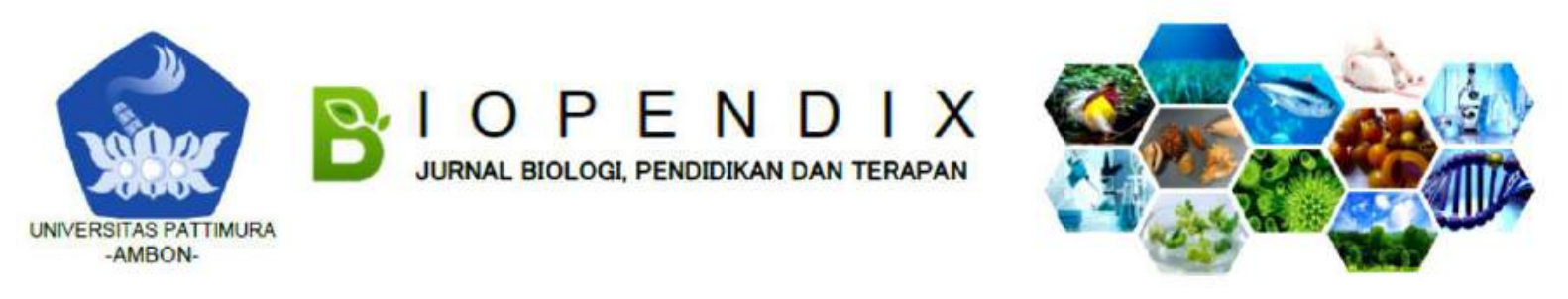

\title{
PERBEDAAN HASIL BELAJAR IPA BIOLOGI \\ MENGGUNAKAN MODEL PEMBELAJARAN \\ PROBLEM BASED LEARNING (PBL) DAN GROUP INVESTIGATION (GI)
}

\author{
Ester Stasya Lawalata ${ }^{1}$, Alwi Smith ${ }^{2}$, S. Liline ${ }^{\star 2}$ \\ 1'Alumni Program Studi Pendidikan Biologi; ${ }^{2}$ Program Studi Pendidikan Biologi \\ *Corresponding author: Alwi Smith; e-mail: asmith.unpatti@gmail.com
}

\begin{abstract}
Background: One of the causes of students' lack of understanding of a concept is teacher-centered learning and a lack of motivation from students in following the learning process. Then we need an innovative learning model that can help students in the learning process. To achieve learning objectives, teachers are required to be able to choose suitable learning models to be applied at an educational level.

Method: This research was conducted from January 14 to February 14, 2020 using descriptive methods, student learning outcomes are seen through the final value that is seen based on cognitive aspects (LKS), affective and psychomotor and pre-post test scores. Measurement data were analyzed using the $t$ test formula.

Results: Based on the $t$ test, obtained the results of tcount 1.573 and ttable 2.010, tcount $<$ ttable, the hypothesis $(\mathrm{H} 1)$ was rejected and $(\mathrm{H} 0)$ was accepted.

Conclusion: There is no difference in the learning outcomes of students taught using the Problem Based Learning model and Group Investigation on the material of the human digestive system in class VIII SMP Negeri 7 Ambon, but there is an increase in learning outcomes after teaching and learning using the Problem Based Learning and Group Investigation models so the results of the t-test show that tcount $<$ ttable $(1.573<2.010)$.
\end{abstract}

Keywords: Problem based learning, Group investigation, Learning outcomes, Human digestive system

\section{Abstrak}

Latar Belakang: Salah satu penyebab kurangnya pemahaman siswa terhadap suatu konsep adalah pembelajaran yang terpusat pada guru dan kurangnya motivasi dari diri siswa dalam mengikuti proses pembelajaran. Maka diperlukan suatu model pembelajaran yang inovatif yang dapat membantu siswa dalam proses pembelajaran. Untuk mencapai tujuan pembelajaran, guru dituntut untuk bisa memilih model pembelajaran yang cocok untuk diterapkan dalam suatu tingkat pendidikan.

Metode: Penelitian ini dilaksanakan dari tanggal 14 Januari - 14 Februari 2020 dengan menggunakan metode deskriptif, hasil belajar siswa terlihat melalui nilai akhir yang dilihat berdasarkan aspek kognitif (LKS), afektif dan psikomotorik serta nilai pre-post test. Data hasil pengukuran dianalisis menggunakan rumus uji t.

Hasil: Berdasarkan uji t, diperoleh hasil thitung 1,573 dan $t_{\text {tabel }} 2,010$, thitung $<t_{\text {tabel }}$ maka hipotesis $\left(H_{1}\right)$ ditolak dan $\left(\mathrm{H}_{0}\right)$ diterima.

Kesimpulan: Tidak ada perbedaan hasil belajar siswa yang diajarkan menggunakan model pembelajaran Problem Based Learning dan Group Investigation materi sistem pencernaan manusia pada kelas VIII SMP Negeri 7 Ambon, tetapi ada peningkatan hasil belajar setelah melakukan proses belajar mengajar dengan menggunakan model Problem Based Learning dan Group Investigation sehingga hasil uji-t menunjukkan bahwa thitung <tabel $(1,573<2,010)$.

Kata Kunci: Problem based learning, Group investigation, Hasil belajar, Sistem pencernaan manusia 


\section{PENDAHULUAN}

Pendidikan adalah upaya sadar yang diarahkan untuk mempersiapkan peserta didik melalui kegiatan pengajaran, bimbingan dan latihan bagi perannya dimasa yang akan datang untuk memiliki kekuatan spiritual keagamaan, pengendalian diri, kepribadian, kecerdasan, akhlak mulia, serta keterampilan yang diperlukan dalam masyarakat, bangsa dan Negara (Hasibuan \& Moedjiono, 2008). Pembelajaran biologi yang berpusat pada siswa dimaksudkan untuk melibatkan siswa dalam mengkontruksi sendiri pengetahuanya sehingga siswa lebih dominan dalam pembelajaran (Hasibuan \& Moedjiono, 2008).

Sudijono (2012), mengungkapkan bahwa hasil belajar merupakan sebuah tindakan evaluasi yang dapat mengungkap aspek proses berpikir (cognitive domain) juga dapat mengungkap aspek kejiwaan lainnya, yaitu aspek nilai atau sikap (affective domain) dan aspek keterampilan (psychomotor domain) yang melekat pada diri setiap individu peserta didik.

$$
\text { Untuk menciptakan suasana }
$$

pembelajaran yang kondusif dan menyenangkan perlu adanya pembelajaran yang menarik sehingga siswa tidak merasa terbebani dengan materi yang harus dikuasai. Dalam rangka mengimplementasikan berlakunya kurikulum 2013, guru perlu mengantisipasinya dengan menerapkan model-model pembelajaran yang menunjang rencana tersebut. Salah satu model pembelajaran yang dapat digunakan yaitu model Problem Based Learning (PBL) dan model Group Investigation (Gl) (Rusmono, 2012). Menurut Komalasari (2011) model problem based learning (PBL) harus memusatkan masalah hidupnya yang bermakna bagi siswa, peran guru dalam menyajikan masalah, mengajukan pertanyaan dan memfasilitasi penyelidikan dan dialog. Model pembelajaran Group Investigation (Gl) adalah model pembelajaran kooperatif yang menekankan pada proses pencarian pengetahuan dari pada transfer pengetahuan. Siswa dipandang sebagai subjek belajar yang perlu dilibatkan secara aktif dalam proses pembelajaran melalui berbagai aktivitas dengan demikian siswa diarahkan untuk menemukan sendiri berbagai fakta, membangun konsep dan nilai-nilai baru yang diperlukan untuk kehidupannya (Rusmono, 2012).

Berdasarkan observasi awal yang dilakukan pada guru mata pelajaran IPA dan juga siswa-siswi kelas VIII SMP Negeri 7 Ambon ditemukan beberapa masalah atau kelemahan yang dihadapi oleh guru mata pelajaran. Masalah yang dihadapi guru mata pelajaran khususnya IPA yaitu terkait partisipasi siswa yang rendah dalam kegiatan pembelajaran, siswa kurang perhatian dalam menerima pelajaran, dominasi siswa tertentu dalam proses pembelajaran dan siswa kurang tertarik dengan cara guru menyampaikan materi. Pada pembelajaran IPA Biologi konsep pencernaan manusia kelas VIII SMP Negeri 7 Ambon, dari data nilai akhir siswa pada semester satu dari tahun ke tahun sampai tahun 2017 (tahun 2016 sebanyak 30\% dan tahun 2017 sebanyak 40\%) rata-rata nilai pada kelas VIII tidak memenuhi KKM. Nilai kriteria ketuntasan minimal (KKM) pada SMP Negeri 7 Ambon yaitu 69. Sebanyak $40 \%$ siswa kelas VIII nilainya menurun pada mata pelajaran sistem pencernaan manusia. Tampak bahwa keaktifan dan kinerja dari guru belum optimal. Dalam proses pembelajaran, guru cenderung menggunakan model pembelajaran konvensional untuk mencapai hasil belajar siswa.Untuk itu peneliti tertarik melakukan penelitian dengan menggunakan model problem based learning (PBL) dan model group investigation (Gl). Peneliti memilih kedua model ini karena dapat meningkatkan motivasi belajar siswa, keaktifan siswa pada proses pembelajaran untuk saling bekerjasama dan berinteraksi antar siswa dalam kelompok tanpa memandang latar belakang.

Model problem based learning (PBL) dan model group investigation (GI), peneliti memilih kedua model ini untuk dipadukan alasannya karena berdasarkan beberapa referensi jurnal dan skripsi yang peneliti baca belum ada penelitian yang memadukan kedua model ini dan peneliti juga tertarik dengan kedua model ini untuk dilakukan penelitian karena pada model problem based learning, siswa diarahkan untuk memecahkan masalah sedangkan pada model group investigation, siswa 
diarahkan untuk melakukan penyelidikannya sendiri sesuai dengan fakta atau konsep yang diberikan. Dengan demikian, perlu diterapkan model-model pembelajaran inovatif yang dapat memicu keaktifan dan meningkatkan hasil belajar terhadap konsep IPA biologi. Berdasarkan latar belakang di atas, maka peneliti merasa perlu untuk melakukan penelitian terkait: "Perbedaan Hasil Belajar IPA (Biologi) dengan Menggunakan Model Pembelajaran Problem Based Learning (PBL) dan Group Investigation (Gl)".

\section{METODE}

Penelitian ini dilakukan dengan menggunakan tipe penelitian komparatif yaitu, penelitian yang dilakukan dengan cara membedakan hasil belajar antara kelompok siswa yang diajarkan dengan menggunakan model pembelajaran problem based learning dengan kelompok siswa yang diajarkan dengan menggunakan model pembelajaran group investigation. Penelitian ini dilakukan pada tanggal 14 Januari 2020 s/d 14 Februari 2020 tahun pelajaran 2019/202 yang bertempat di SMP Negeri 7 Ambon.
Subjek pada penelitian ini adalah siswa kelas $\mathrm{VIII}^{1}$ dan $\mathrm{VIII}^{2}$ program MIPA SMP Negeri 7 Ambon yang masing-masing kelasnya terdiri dari 30 siswa. Variabel dalam penelitian ini dapat dikelompokan menjadi dua, yaitu variabel bebas (independent variable) dan variabel terikat (dependent variable) (Sudjana, 2011). Variabel bebas yaitu model pembelajaran problem based learning dan group investigation dan variaebl terikat yaitu hasil belajar siswa pada materi sistem pencernaan manusia yang diperoleh setelah proses pembelajaran.

\section{HASIL DAN PEMBAHASAN \\ Hasil}

\section{Tes Awal}

Klasifikasi perolehan hasil tes awal siswa dilakukan sebelum proses pembelajaran berlangsung dengan menggunakan materi sistem pencernaan manusia. Perolehan hasil tes awal siswa pada kelas Problem Based Learning dan Group Investigation dapat dilihat pada Tabel 1 berikut.

Tabel 1. Klasifikasi presentase hasil tes awal siswa pada kelas Problem Based Learning dan Group Investigation

\begin{tabular}{cccccc}
\hline \multirow{2}{*}{ Interval } & \multicolumn{2}{c}{ Kelas $P B L$} & \multicolumn{2}{c}{ Kelas GI } & \multirow{2}{*}{ Kualifikasi } \\
\cline { 2 - 5 } & Frekuensi & $(\%)$ & Frekuensi & $(\%)$ & Tuntas \\
\hline$>69$ & 10 & $25 \%$ & 8 & $20 \%$ & Gagal \\
$<69$ & 20 & $75 \%$ & 22 & $80 \%$ & \\
Jumlah & 30 & $100 \%$ & 30 & $100 \%$ & \\
\hline
\end{tabular}

Berdasarkan Tabel 1 diatas maka, data tes awal siswa untuk kelas Problem Based Learning terdapat 10 orang siswa (25\%) memperoleh nilai pada interval $(>69)$ dengan kualifikasi tuntas dan 20 orang siswa $(75 \%)$ memperoleh nilai interval $(<69)$ dengan kualifikasi gagal, sedangkan untuk kelas Group Investigation terdapat 8 siswa $(20 \%)$ yang memperoleh nilai pada interval (>69) dengan kualifikasi tuntas dan 22 siswa $(80 \%)$ memperoleh nilai $(<69)$ dengan kualifikasi gagal.

\section{Deskripsi Penilaian Siswa Selama Proses Belajar Mengajar}

Penilaian selama proses belajar mengajar dilaksanakan dengan berpatokan pada 3 aspek yaitu aspek kognitif, aspek afektif dan aspek psikomotor. Penilaian aspek kognitif dilakukan melalui lembar kerja siswa (LKS) sedangkan pada aspek afektif dan psikomotor merupakan penilaian langsung yang dilakukan selama proses belajar mengajar berlangsung pada materi sistem pencernaan manusia. 


\section{a. Hasil Belajar Kognitif Siswa}

Berdasarkan LKS yang digunakan untuk melihat hasil kerja siswa pada kelas Problem Based Learning dan Group
Investigation dapat dilihat pada Tabel 2 berikut.

Tabel 2. Klasifikasi presentase hasil penilaian apek kognitif pada kelas Problem Based Learning dan Group Investigation

\begin{tabular}{cccccc}
\hline \multirow{2}{*}{ Interval } & \multicolumn{2}{c}{ Kelas PBL } & \multicolumn{2}{c}{ Kelas GI } & \multirow{2}{*}{ Kualifikasi } \\
\cline { 2 - 5 } & Frekuensi & $(\%)$ & Frekuensi & $(\%)$ & \\
\hline$>69$ & 30 & $100 \%$ & 30 & $100 \%$ & Tuntas \\
$<69$ & - & - & - & - & Gagal \\
Jumlah & 30 & $100 \%$ & 30 & $100 \%$ & \\
\hline
\end{tabular}

Berdasarkan Tabel 2 diatas maka, data hasil penelitian aspek kognitif siswa pada kelas Problem Based Learning dan 30 siswa (100\%) memperoleh nilai pada interval (>69) dengan kualifikasi tuntas, sedangkan untuk kelas Group Investigation terdapat 30 siswa (100\%) memperoleh nilai pada interval (>69) dengan kualifikasi tuntas.

\section{b. Hasil Belajar Afektif Siswa}

Penilaian hasil belajar afektif siswa diperoleh melalui pengamatan terhadap sikap siswa di kelas. Data kualifikasi penugasan afektif siswa dengan menggunakan kedua model pembelajaran ini dapat dilihat pada Tabel 3 berikut.

Tabel 3. Klasifikasi presentase hasil penilaian apek afektif pada kelas Problem Based Learning dan Group Investigation

\begin{tabular}{cccccc}
\hline \multirow{2}{*}{ Interval } & \multicolumn{2}{c}{ Kelas PBL } & \multicolumn{2}{c}{ Kelas GI } & \multirow{2}{*}{ Kualifikasi } \\
\cline { 2 - 5 } & Frekuensi & $(\%)$ & Frekuensi & $(\%)$ & \\
\hline$>69$ & 30 & $100 \%$ & 30 & $100 \%$ & Tuntas \\
$<69$ & - & - & - & - & Gagal \\
Jumlah & 30 & $100 \%$ & 30 & $100 \%$ & \\
\hline
\end{tabular}

Berdasarkan Tabel 3 diatas maka diperoleh hasil sebagai berikut, kelas Problem Based Learning terdapat 30 siswa $(100 \%)$ memperoleh nilai pada interval (>69) dengan kualifikasi tuntas, sedangkan untuk kelas Group Investigation terdapat 30 siswa (100\%) memperoleh nilai pada interval (>69) dengan kualifikasi tuntas.

\section{c. Hasil Belajar Psikomotor Siswa}

Penilaian hasil belajar psikomotor pada masing-masing kelas berdasarkan pengamatan selama proses belajar mengajar berlangsung dapat dinilai pada Tabel 4 berikut.

Tabel 4. Klasifikasi presentase hasil penilaian apek psikomotor pada kelas Problem Based Learning dan Group Investigation

\begin{tabular}{cccccc}
\hline \multirow{2}{*}{ Interval } & \multicolumn{2}{c}{ Kelas PBL } & \multicolumn{2}{c}{ Kelas GI } & \multirow{2}{*}{ Kualifikasi } \\
\cline { 2 - 5 } & Frekuensi & $(\%)$ & Frekuensi & $(\%)$ & \\
\hline$>69$ & 30 & $100 \%$ & 30 & $100 \%$ & Tuntas \\
$<69$ & - & - & - & - & Gagal \\
Jumlah & 30 & $100 \%$ & 30 & $100 \%$ & \\
\hline
\end{tabular}

Berdasarkan Tabel 4 diatas maka data hasil penelitian aspek psikomotor untuk masing-masing kelas sebagai berikut, kelas Problem Based Learning terdapat 30 siswa 
$(100 \%)$ memperoleh nilai pada interval (>69) dengan kualifikasi tuntas, sedangkan untuk kelas Group Investigation terdapat 30 siswa (100\%) memperoleh nilai pada interval (>69) dengan kualifikasi tuntas. (lampiran 29 dan 32)

\section{Tes akhir (Tes formatif/akhir)}

Setelah proses pembelajaran selesai, dilakukan tes formatif/akhir untuk mengetahui kemampuan siswa dalam memahami konsep sesuai dengan model pembelajaran yang sudah diterapkan pada masing-masing kelas. Data tingkat penugasan siswa pada tes akhir menggunakan acuan KKM yang dapat diperlihatkan pada Tabel 5 berikut.

Tabel 5. Klasifikasi presentase hasil penilaian Tes akhir (Tes formatif/akhir) pada kelas Problem Based Learning dan Group Investigation

\begin{tabular}{cccccc}
\hline \multirow{2}{*}{ Interval } & \multicolumn{2}{c}{ Kelas PBL } & \multicolumn{2}{c}{ Kelas GI } & \multirow{2}{*}{ Kualifikasi } \\
\cline { 2 - 5 } & Frekuensi & $(\%)$ & Frekuensi & $(\%)$ & \\
\hline$>69$ & 30 & $100 \%$ & 30 & $100 \%$ & Tuntas \\
$<69$ & - & - & - & - & Gagal \\
Jumlah & 30 & $100 \%$ & 30 & $100 \%$ & \\
\hline
\end{tabular}

Berdasarkan Tabel 5 diatas maka, data hasil tes akhir siswa bahwa pada kelas Problem Based Learning terdapat 30 siswa $(100 \%)$ memperoleh nilai pada interval (>69) dengan kualifikasi tuntas, sedangkan untuk kelas Group Investigation terdapat 30 siswa $(100 \%)$ memperoleh nilai pada interval (>69) dengan kualifikasi tuntas. Hasil tes akhir pada kelas Problem Based
Learning dan Group Investigation sudah mencapai KKM (>69).

\section{Nilai Akhir (NA)}

Nilai dari aspek kognitif, afektif dan psikomotor kemudian dihitung untuk mencari Nilai Akhir (NA) pada kelas Problem Based Learning dan kelas Group Investigation terdapat pada Tabel 6 berikut.

Tabel 6. Klasifikasi Presentase Nilai Akhir

\begin{tabular}{cccccc}
\hline \multirow{2}{*}{ Interval } & \multicolumn{2}{c}{ Kelas PBL } & \multicolumn{2}{c}{ Kelas GI } & \multirow{2}{*}{ Kualifikasi } \\
\cline { 2 - 5 } & Frekuensi & $(\%)$ & Frekuensi & $(\%)$ & \\
\hline$>69$ & 30 & $100 \%$ & 30 & $100 \%$ & Tuntas \\
$<69$ & - & - & - & - & Gagal \\
Jumlah & 30 & $100 \%$ & 30 & $100 \%$ & \\
\hline
\end{tabular}

Berdasarkan Tabel 6 diatas maka data hasil presentase Nilai Akhir untuk masingmasing kelas sebagai berikut, kelas Problem Based Learning terdapat 30 siswa $(100 \%)$ memperoleh nilai pada interval (>69) dengan kualifikasi tuntas, sedangkan untuk kelas Group Investigation terdapat 30 siswa $(100 \%)$ memperoleh nilai pada interval (>69) dengan kualifikasi tuntas.
5. Perhitungan Mean, Simpangan Baku, dan Uji-t pada kelas Problem Based Learning dan kelas Group Investigation

Dari hasil belajar serta perhitungan mean, simpangan baku, dan uji-t untuk kelas Problem Based Learning dan kelas Group Investigation diperoleh hasil seperti pada tabel 7 berikut. 
Tabel 7. Perhitungan Mean, Simpangan Baku, dan Uji-t

\begin{tabular}{ccccccc}
\hline Kelas & Variabel & N & Mean & SB & t-hit & t-tab \\
\hline VII $^{2}$ & Problem Based Learning & 30 & $\mathbf{8 4 , 8 0}$ & 800.15 & 1,573 & 2,010 \\
VII $^{1}$ & Group Investigation & 30 & $\mathbf{8 4 , 2 9}$ & 215.17 & & \\
\hline
\end{tabular}

Berdasarkan Tabel 7 diatas maka, terlihat bahwa mean dari skor hasil belajar siswa pada kelas Group Investigation lebih kecil dari pada kelas Problem Based Learning. Hal ini menunjukan bahwa kemampuan hasil belajar siswa pada kelas Problem Based Learning lebih baik dibandingkan kemampuan hasil belajar siswa pada kelas Group Investigation, dan untuk memperjelas perbedaan hasil belajar siswa pada kedua kelas tersebut perlu dilakukan uji-t dan diperoleh hasil thitung $=$ 1,573 dan $t_{\text {tabel }}=2,010$. Oleh karena itu, thitung $_{\text {a }} \mathrm{t}_{\text {tabel, }}$ maka hipotesis $\left(\mathrm{H}_{1}\right)$ ditolak dan $\left(\mathrm{H}_{0}\right)$ diterima yang memperlihatkan bahwa tidak ada perbedaan hasil belajar siswa yang diajarkan dengan menggunakan model Problem Based Learning dan model Group Investigation.

\section{Pembahasan}

\section{Tes Awal (Pre Tes)}

Sebelum melakukan proses kegiatan belajar mengajar (KBM) siswa kelas $\mathrm{VIII}^{1}$ dan VIII' dilakukan tes awal (pre test), menurut Wenno (2010), tes ini dilaksanakan dengan tujuan untuk menyiapkan siswa dalam proses belajar mengajar karena dengan tes awal pikiran mereka akan terfokus pada soal yang mereka kerjakan, untuk mengetahui tingkat-tingkat kemajuan siswa sehubungan dengan proses pembelajaran, untuk mengetahui kemampuan awal yang dimiliki siswa mengenai materi yang akan diajarkan.

Berdasarkan data kualifikasi tes awal siswa (Tabel 1) pada kelas Problem Based Learning menunjukan 20 orang siswa berada pada kualifikasi gagal $(75 \%)$ dengan nilai dibawah KKM (69) dan kemampuan tes awal siswa pada kelas Group Investigation 22 orang siswa berada pada kualifikasi gagal (80\%) dengan nilai dibawah KKM (69). Hal ini disebabkan karena materi pembelajaran belum pernah diajarkan dan setiap siswa memiliki kemampuan berpikir yang berbeda-beda.

\section{Penilaian Siswa Selama Proses Belajar Mengajar}

Dalam proses pembelajaran dengan menggunakan model Problem Based Learning dan model Group Investigation, terdapat 3 aspek penilaian yang dapat digunakan oleh guru dalam menilai kemampuan siswa. Menurut Bloom (2012), ketiga aspek itu antara lain aspek kognitif, afektif dan psikomotor. Aspek kognitif meliputi kemampuan berpikir, kompetensi memperoleh pengetahuan, pengenalan, pemahaman. Aspek afektif meliputi sikap, nilai perasaan, emosi serta derajat penerimaan atau penolakan suatu objek dalam kegiatan belajar-mengajar. Aspek psikomotor merupakan kompetensi melakukan pekerjaan melibatkan anggota badan serta kompetensi yang berkaitan dengan gerakan fisik seperti refleks, keterampilan, gerakan dasar (Santisusanti, 2013).

\section{a. Hasil Belajar Siswa Yang Diajarkan Dengan Menggunakan Model (Problem Based Learning dan Group Investigation). \\ Pada penilaian aspek kognitif, aspek} afektif dan aspek psikomotor kelas Problem Based Learning, siswa dibagi menjadi 2 kelompok dan masing-masing kelompok terdiri dari 15 orang. Dalam kegiatan belajar mengajar pada kelas Problem Based Learning setiap kelompok mengerjakan setiap LKS dan mempresentasikannya, tiap kelompok mampu mengerjakannya. Sehingga pada penilaian aspek kognitif ini menunjukan bahwa 30 siswa (100\%) mencapai ketuntasan belajar dibandingkan dengan kelas Group Investigation dengan klasifikasi yang berbeda-beda. Penilaian aspek afektif dan penilaian psikomotor pada kelas Problem Based Learning berbeda dengan kelas Group Investigation dimana kelas Problem Based Learning lebih tinggi. 


\section{b. Hasil Penilaian Selama Proses Kegiatan Belajar Mengajar Dengan Menggunakan Model (Problem Based Learning dan Group Investigation).}

Pada penilaian aspek kognitif, terlihat bahwa seluruh siswa (100\%) berhasil walaupun dengan klasifikasi berbeda-beda (Tabel 2). Keberhasilan siswa pada aspek kognitif dilihat dari presentase pencapaian proses melalui lembar kerja siswa (LKS) dimana masing-masing siswa dapat menyelesaikan langkah-langkah yang ada pada LKS pada setiap pertemuan.

Pada penilaian afektif dan psikomotor (Tabel 3 dan 4) pada umumnya siswa masuk dalam klasifikasi sangat baik, baik dan cukup, tetapi masih ada juga siswa yang masuk dalam klasifikasi kurang. Siswa yang masuk dalam klasifikasi sangat baik, baik dan cukup menunjukan sikap positif pada saat mengikuti proses pembelajaran dari pertemuan pertama sampai pertemuan kedua, siswa efektif dalam membuat pertanyaan, mencari jawaban (solusi) dan mempresentasikan pertanyaan dan jawaban masing-masing sedangkan siswa yang masuk dalam klasifikasi kurang menunjukan sikap yang kurang positif dalam mengikuti proses pembelajaran, hal ini disebabkan karena siswa belum membuat jawaban dan malu-malu ada juga siswa yang main-main sehingga proses pembelajaran kurang aktif dan efektif.

\section{Tes Akhir ( Tes Formatif )}

Dalam proses belajar mengajar, penting untuk melakukan tes akhir yang bertujuan untuk mengetahui apakah semua meteri pelajaran yang tergolong penting sudah dikuasai dengan sebaik-baiknya oleh siswa. Nilai tes akhir diharapkan lebih baik atau meningkat dibandingkan dengan nilai tes awal, karena siswa telah mempelajari materi yang diberikan oleh guru.

Hasil tes akhir (formatif) siswa pada Tabel 5 menggambarkan keberhasilan pada kedua model dengan meningkatnya hasil tes akhir antara kelas Problem Based Learning dan kelas Group Investigation. Presentase pencapaian tes akhir pada kelas Problem Based Learning sebanyak 30 siswa (100\%) mampu mencapai ketuntasan belajar sedangkan tes akhir pada kelas Group Investigation 30 siswa (100\%) mampu mencapai ketuntasan. Hasil tersebut menunjukan bahwa pada kelas Problem Based Learning dan kelas Group Investigation sama tetapi nilai akhir pada kedua kelas berbeda.

\section{Nilai Akhir}

Nilai akhir adalah nilai baik berupa angka atau huruf yang melambangkan tingkat keberhasilan peserta didik setelah mereka mengikuti program pendidikan pada jenjang pendidikan tertentu dalam jangka waktu yang telah ditentukan. Hasil belajar dapat terjadi dalam bentuk perubahan tingkah laku pada siswa, yang dapat diamati dan diukur bentuk perubahan pengetahuan dan sikap serta keterampilan, perubahan tersebut dapat diartikan terjadinya peningkatan dan pengembangan yang lebih baik dibandingkan dengan sebelumnya (Hamalik, 2009).

Nilai akhir siswa disajikan dalam bentuk deskriptif yang diperoleh dari nilai proses (6P) dan nilai tes Formatif (4F). Pencapaian kompetensi siswa yang meliputi aspek kognitif siswa dari hasil penilaian proses kognitif dalam mengerjakan LKS, aspek afektif dan aspek psikomotor dalam lembaran penilaian serta hasil tes formatif dapat dilihat dari perolehan hasil nilai akhir pada siswa kelas Problem Based Learning dan kelas Group Investigation merupakan penggabungan dari penilaian kognitif (LKS dan nilai tes formatif/akhir), penilaian afektif dan penilaian psikomotor. Hasil nilai akhir pada kelas Problem Based Learning dan kelas Group Investigation telah mencapai ketuntasan sudah menggambarkan keberhasilan siswa pada KKM 69.

\section{Hasil Hipotesis}

Berdasarkan hasil analisis nilai akhir siswa, materi sistem pencernaan manusia dapat dilihat bahwa pada kelas Problem Based Learning mendapat nilai hasil belajar siswa lebih tinggi yaitu dengan jumlah keseluruhan nilai akhir (NA) 81,63 sedangkan dari kelas Group Investigation mendapat nilai hasil belajar siswa yaitu dengan jumlah keseluruhan nilai akhir (NA) 81,48. Tabel 6 untuk kelas Problem Based Learning terdapat 30 siswa (100\%) memperoleh nilai pada interval $(>69)$ dengan kualifikasi tuntas, sedangkan untuk kelas Group Investigation terdapat 30 siswa 
(100\%) memperoleh nilai pada interval (>69) dengan kualifikasi tuntas.

Sudjana (2011), mengartikan hipotesis adalah asumsi atau dugaan mengenai suatu hal yang dibuat untuk menjelaskan hal itu yang sering dituntut untuk melakukan pengecekannya. Atas dasar dua definisi diatas maka dapat disimpulkan bahwa hipotesis adalah jawaban atau dugaan sementara yang harus diuji lagi kebenarannya.

Dari data hasil nilai akhir maka dilakukan perhitungan rata-rata dan simpangan baku dari kelas Problem Based Learning dan kelas Group Investigation, mendapatkan hasil thitung <t tabel $(1,573<$ $2,010)$, maka hipotesis $\left(\mathrm{H}_{1}\right)$ ditolak dan $\left(\mathrm{H}_{0}\right)$ diterima yang memperlihatkan bahwa tidak ada perbedaan hasil belajar siswa kelas VIII SMP NEGERI 7 Ambon yang diajarkan dengan menggunakan model pembelajaran Problem Based Learning dan Group Investigation pada materi sistem pencernaan manusia.

Berdasarkan penelitian yang telah dilakukan, dan hasil perhitungan uji-t didapat bahwa tidak ada perbedaan hasil belajar antara kedua model yang diajarkan. Hal ini berdasarkan penelitian awal bahwa kedua kelas memiliki kemampuan yang sama. Kemudian perlakuan yang sama pada kedua kelas seperti diawal pembelajaran, peneliti menunjukan masalah berupa gambar kelainan atau penyakit pada sistem pencernaan manusia untuk siswa pecahkan. Hanya pada pemberian materi dan diskusi yang membedakan antara model PBL dan GI.

Pada pembelajaran dengan menggunakan model PBL dan Gl setiap langkah-langkah pembelajaran diterapkan dengan baik pada kedua kelas. Kekurangan setelah menerapkan kedua model yaitu model pembelajaran PBL dan GI pada penelitian ini adalah pada pembagian kelompok hanya ada dua kelompok besar yang didalamnya jumlah siswa terdiri dari sepuluh sampai lima belas siswa. Kemudian penggunaan waktu yang diberikan guru kepada siswa belum mampu dimanfaatkan dengan baik oleh siswa pada saat pelaksanaan pembelajaran berlangsung seperti diskusi dan presentasi. $\mathrm{Hal}$ ini membuat proses pembelajaran tidak berjalan dengan baik. Selain karena faktor- faktor diatas yang memperlihatkan tidak ada perbedaan hasil belajar antara kedua model, setelah peneliti melakukan uji secara statistik hasilnya menunjukan bahwa tidak ada perbedaan hasil belajar karena pada pengujian secara statistik memerlukan data yang lebih besar berupa data hasil belajar siswa.

Berdasarkan hasil penelitian memperlihatkan bahwa tidak ada perbedaan hasil belajar siswa yang diajarkan menggunakan model pembelajaran Problem Based Learning dan Group Investigation materi sistem pencernaan manusia. Tetapi ada peningkatan hasil belajar pada kedua kelas setelah dilakukan proses belajar mengajar dengan menggunakan model Problem Based Learning dan Group Investigation. Peningkatan hasil belajar siswa menggunakan model PBL dan Gl dapat dilihat pada hasil belajar siswa pada kedua kelas yang nilainya mencapai KKM (>69) dengan kualifikasi tuntas, dapat dilihat bahwa pada kelas PBL mendapat nilai hasil belajar siswa lebih tinggi yaitu dengan jumlah keseluruhan nilai akhir (NA) 81,63 sedangkan dari kelas Gl mendapat nilai hasil belajar siswa yaitu dengan jumlah keseluruhan nilai akhir (NA) 81,48, ini menunjukan bahwa pada kedua model ini hasil akhirnya meningkat dan pada jumlah nominalnya menunjukan hasil berupa angka yang tidak jauh berbeda antara kedua model yang digunakan.

\section{SIMPULAN}

Berdasarkan data hasil penelitian dan uji hipotesis maka dapat disimpulkan bahwa, tidak ada perbedaan hasil belajar siswa yang diajarkan menggunakan model pembelajaran Problem Based Learning dan Group Investigation materi sistem pencernaan manusia pada kelas VIII SMP Negeri 7 Ambon, tetapi ada peningkatan hasil belajar setelah melakukan proses belajar mengajar dengan menggunakan model Problem Based Learning dan Group Investigation sehingga hasil uji-t menunjukkan bahwa thitung <tabel $(1,573<2,010)$. 


\section{DAFTAR PUSTAKA}

Bloom, S. 2012. Penialian Hasil Belajar dengan Teknik Analisis Hasil Belajar. Yogyakarta: Universitas Sanata Darma.

Hamalik, O. 2009. Proses Belajar Mengajar. Jakarta: PT Bumi Aksara.

Hasibua \& Moedjiono.2008. Proses Belajar Mengajar. Bandung. PT Remaja Rosdakarya.

Komalasari, K. 2011. Pembelajaran Kontekstual Konsep dan Aplikasi.Bandung: Refika Aditama.
Rusmono, 2012. Strategi Pembelajaran dengan Problem Based Learning. Bogor: Ghalia Indonesia.

Santisusanti, 2013. Strategi belajar mengajar. Jakarta: PT. Rineka Cipta.

Sudijono, A. 2012. Pengantar evaluasi pendidikan.Jakarta: PT. Raja Grafindo Persada.

Sudjana, 2011. Penilaian Hasil Belajar Mengajar. Bandung: Remaja Rosdakarya.

Wenno, 2010. Desain Penelitian Pendidikan dan Teknik Analisis Data. Jogjakarta: Grafika Indika. 